\title{
Odnos antropologije i umjetnosti u djelu Rajmunda Kuparea
}

\section{Abstract: The Relationship between Anthropology and Art in the Works of Raimundo Kupareo}

This article discusses the relationship between anthropology and art in the philosophical work of contemporary Croatian philosopher Raimundo Kupareo. Anthropology is the study of man, and art is the study or manifestation of human presence. Man is a being of value that connects mysticism and rationality, knowledge and emotions, idea and matter, anthropology and art. The possibility of a touch between anthropology and art allows for the avoidance of dichotomous tendencies of separation between art and anthropology, works and authors. The artistic process, viewed from anthropological positions, is the process of rise and resurrection of the artist as the author and his/her work as a particular value. The author has been legitimized in the world as a being that conceives different ideas and is able to express them in matter, while his work has been publicly presented as a true, human value without the predetermined exclusivity of belonging to someone. That man presents a value, the same as a work of art, implies that the importance of artwork has been recognized through anthropological laws, in the same way that the value of man has been recognized through art. The article focuses on the artistic process as an existential process opening a man towards another man and his world. So, art and anthropology eliminate the alienation tendencies of man to become an ontologically, metaphysically, aesthetically, existentially, and culturally closed being.

Keywords: Raimundo Kupareo, art, anthropology, aesthetics, value, human subject

\section{Uvod}


Odnos antropologije i umjetnosti može se sagledati na dva načina: kao uspostavljanje realiteta ontologijske provenijencije i kao dohvaćanje biti umjetnosti putem naknadnog konceptualiziranja egzistencijske prakse. No, i jedan i drugi put se pokazuju nedostatnima jer počivaju samo na jednoj dimenziji ljudskog načina postojanja - onoj razumskoj. Antropologija je ljudski govor o čovjeku, umjetnost je, naprotiv, istina ljudskog iskazivanja koja počiva na angažmanu svih ljudskih, a ne samo isključivo racionalnih, elementa te, kao takva, ne podliježe racionalizaciji i razumskom redukcionizmu.

R. Kupareo ovom složenom odnosu pristupa s različitim optikama, želeći naglasiti kako se bît antropologije i bît umjetnosti ne mogu iscrpiti ni jednim predmetnim metodologijskim ograničenjem. Naime, u umjetnosti je na djelu sloboda, a umjetničko djelo je pojavnost tog izraza slobode. Antropologija, promatrana kao filozofijska disciplina, umjetnošću biva obogaćena dimenzijom intuiranja istine i iskustvom sreće. No, sreća, radost i veselje nisu smisao umjetnosti. Umjetnost, prema Kupareu, svoj telos ostvaruje u konaturalnosti i kreativnosti, koju je moguće, po analogiji, dovesti u vezu s Božjim stvaranjem svijeta ni iz čega. Upravo kao djelatnost koja po analogiji participira na stvaranju, umjetnost razotkriva svoj unutarnji smisao - ona je, naime, u funkciji izricanja istine, a ne potvrda principa konzervacije emocionalnih stanja. No Kupareovo neskriveno podređivanje umjetnosti, kao procesa utvarivanja ideje i ideiranja tvari, teologiji i vjeri kao osnovi teologije, neizostavno sadrži redukcionističku metodologiju, a dijelom i narušavanje principa konaturalnosti jer, ako je kršćanski nauk o stvaranju model za razumijevanje umjetničkog procesa, onda je moguće izvesti zaključak, pa i model razumijevanja umjetnosti, kako je svrha i smisao umjetnosti uskrsnuće humanog subjekta ili autora, koji u dotadašnjem besmislu nepostojanja unosi smisao neke ideje, združene s materijom, koja se vremeni i u vremenjenju biva dostupna cijelom ljudskom svijetu. Umjetničko djelo je, stoga, konaturalno zahvaljujući umjetniku.

\section{Reciprocitet antropologijskog i umjetničkog realiteta}

Realitet čovjeka i realitet umjetnosti počivaju na metodologiji reciprociteta. Naime, umjetnost ne počiva na spekulaciji, ona je u samoj svojoj osnovi usmjerena prema utvarenju ideje. Spekulativna dimenzija je dimenzija odvojenosti, dok je dimenzija umjetničkog usmjerena prema otjelovljenom duhu i oduhovljenom tijelu. Metodologija reciprociteta inkluzivne je naravi - koliko je čovjek ostvario 
ideal čovječnosti ${ }^{[1]}$ toliko je sposoban ostvariti i ideal umjetničke vrijednosti očitovane u umjetničkom djelu. Ovim modelom, umjetničko se djelo ne promatra estetskom, već aksiološkom, antropološkom i metafizičkom optikom. Aksiologijom se osvješćuje da je čovjek vrijednost, baš kao što je i umjetnost vrijednost. Vrijednost dakle nije isključivo idealne naravi, ostvarena je u materiji ili tvari te se očituje u djelu - ljudskom i umjetničkom. Čovjek kao djelo vrijednosti omogućuje da se umjetnost poima kao realitet aksiološkoga. Umjetnička vrijednost dakle ne pripada svijetu odvojivosti, ona nema navlastiti bitak. Budući je tako, vrijednost se opire svakom dihotomnom nastojanju, ona, štoviše, progovara o najintimnijem antropološkom ustrojstvu potrebe cjelovitosti. Čovjek je biće mistike i umjetnosti, spoznaje i emocija, riječju biće vrijednosti. Aksiološki supstrat cjelovitosti vidljiv je u zakonitosti inspiracije. Njome biće jezika vrijednosti, dakle umjetnik „intuira bitne elemente ljudskih osjećaja, težnji, napora, strasti itd. koji nadilaze njegove vlastite osjećaje i težnje te postaju općeljudske u nekom umjetničkom djelu“ (Kupareo, Umjetnik i zagonetka života 34). Intuiranjem ${ }^{2]}$ se umjetnik ne stavlja pred zadatak univerzaliziranja svog jastva, on, naprotiv, kao subjekt aksiološke provenijencije, djelajući - formirajući materiju - povezuje mogućnost autentičnog govora, kojim se on sâm neće desubjektivizirati, s općeljudskim zahtjevom da se govor vrijednosti ne izriče samo u konceptualnim shemama.

Ovako određena umjetnost omogućava nam da shvatimo kako se umjetnička apstrakcija razlikuje od filozofijske apstrakcije na način da se produkt filozofijske apstrakcije pronalazi, poima, razumijeva i prebiva u pojmu, dok se produkt umjetničke apstrakcije ne može razumjeti nikako drugačije, nego iz sučeljenosti s preoblikovanom materijom. U njoj se nalazi umjetnik, ali i općeljudska vrijednost. Naime, umjetničkom se djelu ne pristupa s pozicije antropologije dihotomnoga. Ono nije materija bez forme, ni forma odvojiva od materije. Tko pokuša samo razumom zahvatiti proces i produkt umjetničkog intuiranja, upada u zamku antropologije dihotomnog i univerzalizacije jastva ${ }^{[3]}$ Tada umjetničko djelo biva pokoreno konceptom, vrijednost prognana izvan granica ljudskog svijeta, a sâm čovjek, posljedično, reduciran na nešto od ljudskoga - moć razuma. Naprotiv, kada se umjetnost svede na sferu iracionalnoga, tada umjetničko djelo biva bezvrijedno jer se potpunoma prepustilo neuhvatljivosti dionizijskog vitalizma u kojemu se svako značenje zadržava i ujedno iščezava u trenutnoj nepredvidivosti fatumu izručene zbilje. Umjetničkom je djelu moguće pristupiti isključivo s pozicije cjelovitosti, 
komplementarnosti i inkluzivnosti jer: „Jedna vrednota - biće, kao što je umjetničko djelo, koja bi izravno nijekala drugu vrednotu, zanijekala bi sebe, jer bi zanijekala istinu, koja je zapravo biće pod vidom istinitog“ (Kupareo, Čovjek i umjetnost 48). Zanimljivo je da se iz tomističke metafizike, koja je po svojoj naravi spekulativna i konceptualna, izvodi za umjetnost relevantno načelo nekontradikcije. Umjetnost i umjetničko djelo ne počivaju na negaciji, nego na afirmaciji stvarnosti. Umjetnost nije oružje u rukama umjetnika, nego medij aksiološkoga, ontološkoga, etičkoga i antropološkoga. Ovo nipošto ne znači da umjetničko djelo ne progovara o dekadentnim stvarnostima. No, dekadenciji se ne pristupa s horizonta destruiranja realiteta. Konkretno, umjetnost tematski zahvaća „nepoštenje, bračnu nevjernost, ubojstvo, škrtost, blud, pijanstvo, ali kao antitezu kreposti, a ne kao njezinu apologiju“ (Kupareo, Čovjek i umjetnost 48). Apologija destruirane stvarnosti ${ }^{4]}$ sadržane u umjetničkom djelu, sukladno promoviranom načelu, bila bi apologija dekadentnog čovjeka koji u nedostatku realiteta vidi realitet, koji u nedostatku kreposnog vidi krepost i koji u potpunom odsustvu vrijednosnoga pronalazi vrijednost. Dekadencija, dakle, nije u nevjeri ili škrtosti, nego dekadencija nastupa kad estetizirana nevjera postaje vjernost ili kad estetizirana škrtost postaje darežljivost.

Umjetničko djelo jest djelo nekog umjetnika koji može biti, na subjektivnoj razini, vođen nakanama dekadentne provenijencije, no upravo kao djelo, ono nije samo umjetnikovo, nego pripada ontologijskoj zakonitosti subzistentnosti. Naime, ono pronosi i vrijednost koja je neovisna o nakanama umjetnika, ono ga ne univerzalizira, ali ga ne smije niti negirati, umjetnik je uvijek autor, njegovo djelo je njegovo, ali se, kao djelo, od njega odvojilo i zašlo u svijet subzistencije, pripada svima koji se prema njemu odnose, ali svima ne pripada na isti način. Autor je autor djela, ali djelo sad zalazi u odnos s autorima prosudbe i prihvaćanja djela, a ono je mnogostruko.

Umjetnost nije porobljeno čedo esteticizma, nego prvorazredni govor ljudske duhovnosti (Kupareo, Um i umjetnost 53-58). Umjetničko djelo je jedinstveno i ono se ne odjeljuje od vlastite moralne dimenzije $e^{[5]}$ Moderna umjetnos ${ }^{[6]}$ subjektivizira umjetničko djelo te ujedno relativizira njegovu aksiološku i etičku, a samim time i umjetničku dimenziju. Konflikt između umjetnosti i morala je „najčešće u tome što umjetnost, osobito moderna, iznosi na javu tajne intimnog života, i to ne samo kao antitezu kreposti nego kao samosvojne vrijednosti“ (Kupareo, Umjetnik i zagonetka života 24). Svaka umjetnička univerzalizacija subjektivnih umjetnikovih nakana rezultira 
ontologijom partikularnosti. Umjetničko djelo tada postaje desubjektivizirani umjetnik esteticizmom identificiran s nekom od subzistentnih, prethodno egzistencijalno iskusivih, ne-vrijednosti. Ovime umjetnost biva svedena na medij promoviranja privativnih entiteta[?]

Umjetnost, smatra Kupareo, ne može biti privacija volje. Volja postaje privativni entitet ako istinu smjeni nasladom. Volja koja nije dotaknuta mehanizmom privacije svoj smiraj doživljava u spokojstvu, u pomirenosti s razumom. Antropološko utemeljenje umjetničkog užitka sâm užitak dovodi pred svjetlo istine i moralnosti. Naime, spokojstvo volje nije ostvarivo u činjenju zla, jer je zlo privacija dobra. Umjetnički užitak kao spokojstvo volje, sklad razumskoga i voljnoga, čovjeka preplavljuje s radošću, a ono je „znak postignutog savršenstva“ (Kupareo, Um i umjetnost 264). Savršenstvo radosti unutarnjeg je karaktera, ono progovara jezikom antropologije, ontologije, estetike, aksiologije, moralnosti, riječju - jezikom duhovnosti. Nasuprot spokojstvu radosnog čovjeka, čovjek naslade, kao privacije istine i njezine odvojivosti od dobra volje, radost smjenjuje veseljem. A ono nije ništa drugo doli kratkotrajno mahnitanje u prostoru, potpunoma izručenom snazi izvanjskosti. Čovjek veselja je čovjek zamjetljivosti, bučnosti, izražene estetizacije. Antropologija radosti je drugačija od antropologije veselja jer: „Radost odsijeva u osmijehu, veselje u smijehu. I radost i veselje (tuga i plač) mogu pratiti stvaranje kao njegov izljev, ali oni nipošto ne čine njegovu bit“ (Kupareo, Um i umjetnost 264). Umjetnost nije nastala iz radosti, niti iz veselja pa s veseljem i s radošću nije ostvarila svoju svrhu. Ona ne privodi čovjeka užitku odvojenom od istine. Umjetnička spoznaja je konaturalna, njoj odgovara upravo i jedna takva konaturalna intuicija. Realna intuicija zahtijeva realnu opstojnost intuiranog predmeta, dok konaturalna intuicija zahtijeva njegov intencionalan bitak.

R. Kupareo, na liniji filozofije Tome Akvinskoga, razlikuje intelektualnu od umjetničke intuicije te naglašava: „Intelektualnu i umjetničku intuiciju stavljam u navodne znakove kako se ne bi pomislilo da te spoznaje nastaju neovisno o bilo kakvom gnoseološkom ili psihološkom posredniku (medium quo). One su intuitivne u poredbi s osjetilnom spoznajom koja je intuicija u pravom smislu riječi“ (Kupareo, Umjetnik i zagonetka života 38). Osjetilna intuicija se očituje u usmjerenosti prema objektu, u neposrednosti. U umjetničkom procesu, intuicija se ne iscrpljuje u usmjerenosti prema predmetu, ona je konaturalna - iskustvena i nepojmovna. Konaturalnost je su-prirodnost (Kupareo, Umjetnik i zagonetka života 32-33). Ako u raspravu uključimo gnoseološki supstrat, u posjedu smo 
uvida kako se do istine dolazi adekvatnom uporabom razuma dakle spoznajom u skladu s logičkim zakonitostima - naravna mudrost. No, do istine se može doći i na temelju konaturalnosti nadnaravne mudrosti koja razum dovodi do intuiranja istine. Bît umjetničke istine na adekvatan se način može razumjeti ako se dovede u odnos s Božjim stvaranjem svijeta. Bog svijet stvara ex nihilo, slobodnim činom volje. Stvaranje svijeta ne iscrpljuje Božju stvoriteljsku moć, u smislu da je svijet mogao biti stvoren i drugačije. Kontingentnost stvorenja progovara jezikom ontološke sastavljenosti. Sva bića proizašla iz čina stvaranja bića su ograničenog načina bivstvovanja - sva su mogla biti i ne biti, ali, također, ni jedno biće ne iscrpljuje svu savršenost bivstvovanja ${ }^{[8]}$ Jedino je Bog, ontološki i metafizički promatrano, jednostavno biće. Sastavljenost bića je realna, zbiljska i konceptualna.

Umjetničko se stvaranje per analogiam može dovesti u vezu s Božjim stvaranjem. Naime, umjetnik umjetničkim stvaranjem intuira istinu, uzima neku, već postojeću, oformljenu materiju i daje joj neku novu, drugu formu. Ovdje je nužno postaviti pitanje u kakvom se odnosu nalaze forma i materija u procesu umjetničkog stvaranja - konceptualnom ili realnom. Kupareo se u davanju odgovara na ovo pitanje oslanja na Tominu misao te ističe da su „to konceptualne relacije, i u njihovom uvijek novom i izvornom pronalaženju sastoji se umjetničko stvaranje" te dodaje kako ovime nastaje novi red na način da „novi stvoreni odnos između znaka i označenog igra bitnu ulogu u umjetnosti“ (Kupareo, „Osnovne crte“ 189). Umjetničko stvaranje, dakle, nije stvaranje u ontološkom smislu. Njime se nekom nepostojećem entitetu ne daje postojanje, nego se nečemu što postoji na jedan način daje određeni, umjetnički novum. Novost Božjeg stvarateljskog čina je istovremena - ono što nije biva činom stvaranja. Novost umjetničkog je susljedna - ono što jest, susljednim činima zadobiva drugačiji oblik. Prema navedenom, može se izvesti zaključak da umjetničko stvaranje pretpostavlja intuiranje istine, neku ideju u kojoj se očituje originalnost umjetničkog stvaranja, te, na koncu, i neku postojeću stvarnost koja se nalazi u mogućnosti primiti, procesom umjetničkog stvaranja, neku novu formu.

No Kupareo se ne zadržava na pukom ponavljanju tomističkog nauka, nego umjetnosti pridaje jedno novo značenje - promatra je pod personalističkim vidikom ${ }^{[9]}$ Umjetnošću čovjek izlazi iz zatvorenosti svoga jastva, želi sebe ususretiti drugome: „Čovjek, 'zatvoreno biće', želi se očitovati i ući u zatvoreno svetište druge osobe preko bezbrojnih vrsta personifikacije i reifikacije. U 
umjetnosti su one poprimile različite oblike. Katkad je terminus comporationis između pjesničkih stvari i osjećaja (ideja) prilično očit, kao u tradicionalnoj poeziji, katkad je skriven, kao u modernoj“ (Kupareo, „Osnovne crte“ 189). Međutim, Kupareo, inzistirajući na proširenju principa proturječnosti, radikalizira antropološku i estetsko-kulturološku poziciju, inzistirajući na tome da jedna vrijednost ne može biti u suprotnosti s drugom vrijednošću, konkretno - estetsko i moralno se ne može međusobno nijekati. Postavlja se pitanje, jesmo li, prihvaćajući ovo proširenje principa neproturječnosti, upravo narušili „zatvoreno svetište druge osobe“ jer smo u njegovo djelo, unijeli vlastiti moralni sustav? Ovaj prigovor je moguć izvan teleološkog sustava, ali Kupareo iz njega ne izlazi, naprotiv, on inzistira na autonomiji različitih ljudskih disciplina, pa, prema tome, i na autonomiji umjetničkog stvaralaštva. Ono, budući je autonomno, ovisi o pravilima i načelima vlastitima upravo tome području. No, kako se nalazi u humanoj teleologiji ili ostvarenju ljudskosti koja je opća i cjelovita, onda je i to područje i ta disciplina s vlastitim partikularnim pravilima i načelima, podložna općeljudskim i metafizičkim principima, pa je dio teleološke cjeline o kojoj ovisi. Izlazak iz jastva je stoga moguć ako se vrijednost umjetničkog djela ne konfrontira s moralnom vrijednošću, što ne znači da se nasilno konstruira nelegitimna moralna prosudba koja rezultira nastankom inhibitornog estetskog moralizma, odnosno da se estetska vrijednost nekog djela određuje moralnom normom. Estetska i moralna vrijednost su razdvojene, ne mogu supstituirati jedna drugu, ali se i jedna i druga nalaze unutar teleologije humanoga (Kupareo, Um i umjetnost 68-76). Zahvaljujući humanoj teleologiji, umjetnost ne pojačava ljudsku uprostornjenost i uvremenjenost. Umjetnost čovjeka izvlašćuje od „vremenske povezanosti i prostorne doticajnosti, bilo u fizičkom smislu bilo u smislu homogenosti koje im pridaje um“ (Kupareo, Govor umjetnosti 96). Estetiziranje i, posljedično, humaniziranje prostora i vremena, odvaja nas od spaciotemporalnog kontinuuma provodeći nas kroz poimanje prostornosti i vremenitosti. Asinkronizam i asinkorizam pomažu da se asinkronizam drugačijeg vremena i asinkorizam drugačijeg prostora promatraju u konfliktu ili komunikacijskom odnosu stvarnog prostora i estetiziranog prostora, stvarnog vremena i estetiziranog vremena, odnosno estetiziranog vremena i estetiziranog prostora. Da bi se to moglo ostvariti, najprije umjetnik treba spoznajno zahvatiti ideju prostornosti i vremenitosti, on se ne kreće unutar stvarnosti prostora i vremena, nego ga pojmovno zahvaća omogućujući da se u estetiziranom vremenu nastani ideirana i intuirana vrijednost vremena. $\mathrm{Na}$ primjeru arhitekture, Kupareo pokazuje zakonitost estetizirane humane teleologije. Arhitekti vrše 
rekonfiguraciju i preobrazbu mjesta na način da je u „arhitektonskom 'redu' čovjek izražen u svojoj cjelovitosti: duši i tijelu“ (Kupareo, Govor umjetnosti 98). Duša i tijelo, shvaćeni kao formalni i materijalni princip cjelovitosti čovjeka ${ }^{[10]}$ u susretu s preobraženim mjestom u arhitekturi, pridonose antropologizaciji arhitekture. Veza antropologije i asinkorizma u arhitekturi, prostoru arhitekture daje antropološku dimenziju, odnosno u arhitektonskom rješenju neke zgrade ili nekog trga treba iščitavati cjelovitost ljudskog bića!11] Jednoznačno rečeno, u arhitektonskim rješenjima treba dekodirati emocije ljudskog korisnika tog prostora, treba umjeti vidjeti koliko je taj prostor otvoren prema ljudskom mjestu, kako će se korisnici osjećati, hoće li pridonositi osjećaju sreće ili će producirati egzistencijalnu tjeskobu. Dušu i tijelo možemo shvatiti, s odmakom od Kupareove antropologije i estetike, kao paradigmatiku razumijevanja dijalektičnog odnosa realne kvalitete i kvantitete s estetiziranim prostorom i vremenom koji imaju antropološku metarazinu. Umjetnost, budući da prostor i vrijeme ${ }^{[2]}$ diže na višu, ljudskiju, odprirođenu dimenziju, stvara prostor i vrijeme ljudske slobode, a ona se u umjetničkom djelu utvaruje uz pomoć intuicije, stoga se može reći da „u bilo kojem umjetničkom djelu nije najvažnije (iako je potrebno) ono što se gleda, sluša, nego ono što se uočava (intuira)“ (Kupareo, Um i umjetnost 276). Intuirana datost odražava, riječima S. Kierkegaarda, istinu kao subjektivnost, a ne istinu kao objektivnost. Objektivno gledanje neće dovesti do subjektivnog viđenja ideje, objektivno slušanje neće dovesti do subjektivne čujnosti ideje. Ideja se humanom subjektu nadaje putem intuiranja[13]

\section{Umjetnost i antropologija otvorenosti}

Umjetnošću se čovjek ne „zatvara“, ali niti, iako to često tako može izgledati, reificira. Umjetnički proces je proces komunikacije bića koje nije ontološki, metafizički, estetički, aksiološki i egzistencijalno zatvoreno. Umjetnička komunikacija čovjeka izvlači iz dubina alijenacije i postavlja ga u dinamički proces komunikacije sa stvarnim svijetom i stvarnim bićima koja su sposobna stvarati na način unošenja konceptualnih razlika u red realnosti. Umjetničkim ususretnjivanjem sa zbiljom svijeta izbjegava se hermetizam antropologizma. Antropologizam polazi od zatvorenosti čovjeka, njegove samopostavljenosti u redu ontologije, etike, estetike. Samopostavljeni čovjek zatvara se u dimenziju subjektivnosti. Tada prosudba predstavlja samo različite varijacije na istu temu - kako oživotvoriti Protagorin zaziv o čovjeku kao mjerilu svih stvari, onih koje jesu da jesu i 
onih koji nisu da nisu. Kupareo posebno posvećuje pozornost analizi egzistencijalističkog antropologizma u umjetnosti u kojemu je „prenaglašena potpuna neopredjeljivost (indeterminizam) volje i bezgranična autonomija savjesti“ (Kupareo, Umjetnik i zagonetka života 41). Proces umjetničkog stvaranja tada postaje procesom destruiranja svega onoga što se pojedincu postavlja kao prepreka u ostvarenju njegove slobode koja se, u odnosu na sve što nije sadržaj te slobode, manifestira kao negacija. Ništenje svijeta koji nije svijet slobode pojedinca moguć je jer je ljudska sloboda, promatrano primjerice iz perspektive misli J.-P. Sartrea, upravo to: negacija. ${ }^{[14]}$ Ako se konceptu antropologizma negacije priđe manje ostrašćeno, uviđa se da neodređenost ima identitetan odnos prema onome što se ostvaruje kao lišenost svakog sadržaja - Ništa. Ništa jest destrukcija sadržaja tzv. pozitivne stvarnosti, no ono u sebi, kada se oslobodi popudbine antropologizma, obiluje potencijalom da se nadvlada sâm princip neopredjeljivosti. Naime, ništa može biti ono što čovjeku omogućava komunikaciju. Da bi sebe izrekao, čovjek treba biti u mogućnosti reći: „Ne“. „Ne“ tada nije usamljivanje, nego manifestativan oblik autonomije pojedinca bez koje ne može biti ni autorstva. Autorstvo je svojevrsni oblik ne-tebe, ne-drugih, dakle mene (autora) koji se odvaja od drugih - negira ih. No, kada bi autorstvo bilo samo proces negiranja kozmosa drugih, zapalo bi se u prvorazredni egzistencijalistički antropologizam. Tada bi drugi služili isključivo u svrhu isticanja onoga što Kupareo naziva „bezgraničnom autonomijom“. Autorstvo u umjetnosti nije promotor autonomije subjekta već samim time što umjetnik ideju - pa i ideju negacije - ostvaruje u određenom tvorivu ili tvari. Tvorivo ili tvar, kao materijalni uzrok, unosi pukotinu u svijet hermetizma antropologističkog koncepta destruiranja svakoga pozitivnog sadržaja. Modalitet uvjetovanja opstojnosti ništenjem upravo opstojnosti, čovjeka familijarizira s horizontom trajne neodređenosti, neopredjeljivosti, odnosno s horizontom beskonačne autonomije subjekta koji postaje ono što nije na način da nije ono što jest ili što može biti. Kako je ova koncepcija ozvučenje apsurda, Kupareo joj suprotstavlja koncepciju volje koja jest egzistencijalna, ali nije apsurdna. Potonje se ostvaruje dijalektikom dubinskog ja i volje: „Sloboda je neka vrsta misterija zbog zahvata vitalne spontanosti našeg dubinskog „ja“, ali ta se spontanost ne može svesti na čimbenike koji prethode i prate naš izbor; oni ne mogu nužno i nepogrešivo primorati volju da djeluje“ (Kupareo, Umjetnik i zagonetka života 45). Neovisno o pristajanju ili nepristajanju uz apsurd, dolazimo do uvida kako je umjetnost prvorazredno područje ostvarivanja slobode. Ako 
je egzistencija apsurdna, sloboda joj omogućava da se čovjek u činu oslobodi. Dosljedno navedenom, svaki je ljudski čin dobar jer je čin slobode. Naprotiv, ako egzistencija nije apsurdna, slobodom se izriče govor dijalektike volje i dubinskog ja. Prema prvom scenariju, kada se ovakvo poimanje slobode i egzistencije sagleda s razine umjetnosti, umjetnost tada biva lišena svih egzistencijalnih relacija, jedina preostala relacija jest ona s umjetnikom. Vrijednost je tada fundirana u toposu solipsisitičkog kozmosa. Drugi su naprosto irelevantni, drugi se promatraju kao figura koja ograničava ljudsku slobodu, obezvrjeđuje je koegzistencijskim postulatom.

Prema drugom, Kupareu prihvatljivijem scenariju, slobodu nije moguće zahvatiti nikakvim redukcionističkim metodologijama. Slobodom se egzistencija očituje kao ona koja je u sebi i prema drugima slobodna. Relacijski karakter egzistencijalne slobode omogućava da upravo ona integrira sva područja ljudskog djelovanja, baš kao što integrira i sve antropološke vlastitosti. ${ }^{[15]}$ Čovjek je biće razuma, volje i slobode. Sloboda je tkana nitima misterija zato što „nijedno dobro ne može nužno primorati našu volju na djelovanje“ te stoga na egzistencijalnu pozornicu stupa „tajanstveni ali ne besmisleni čimbenik: slobodno samoodređenje (liberum arbitrium)“ (Kupareo, Umjetnik i zagonetka života 44). Umjetnost koja počiva na antropološkim pretpostavkama je, ili umjetnost solipsistički motiviranog pojedinca koji se neprestano i iznova ostvaruje kao biće slobode, ili je, naprotiv, umjetnost kojom se iz područja ljudskog bitka neizostavno dolazi do bitka misterija. Sloboda i misterij se uključuju na liniji promoviranja zahtjeva unošenja strukture brige za svijet koji predstavlja ambijentalnost ljudskom načinu opstojanja. Naime, bez misterija slobode bilo bi nemoguće, drži Kupareo, misaono rekonstruirati put smislenosti slobode, egzistencije i umjetnosti. Kada bi sloboda u svijet unosila samo ono ništavilo koje prethodi ljudskom postojanju, ona bi tada potpunoma bila predana ostvarivanju scenarija destrukcije. No, ako se slobodu veže uz misterij prvenstveno misterij stvaranja, onda se cjelina ljudske egzistencije smješta u okrilje smislenosti. Ontologija smislenosti utemeljena je na misteriju slobode, stvaranja i postojanja dok je ontologija besmislenosti moguća jedino na grobnom humku slobode, istine, dobrote, jednoznačno rečeno grobnom humku postojanja.

Kada se umjetnost i proces umjetničkog stvaranja dovede u analogiju s dinamizmom slobode postaje razvidno kako se smisao umjetničkog djela ne iscrpljuje u estetskom užitku, ${ }^{[16]}$ nego je potpuno predana telosu istine, dobrote i jednoće. Istina umjetničkog djela se prosuđuje temeljem 
kriterija indirektne ontologije. Umjetničko djelo transcendira tvar u kojoj se utvaruje ideja koju umjetnik dohvaća, ono nadalje transcendira dominantan etički sustav vremena ili epohe te, konačno, kad se ideja umjetnika ostvari u tvari, umjetnik i umjetničko djelo zalaze u relaciju odvojenih jednoća ${ }^{[17]}$

Naime, umjetničko djelo nastaje kao posljedica umjetnikovog ideiranja, ali ono, kada je jednom dovršeno, postaje samostalna datost, stvarnost u sebi. No, relacija spram umjetnika tada biva supstituirana relacijom prema ljubiteljima ili poznavateljima umjetnosti. Ovdje se događa drugi oblik ideiranja kojem se snažno suprotstavlja onaj primordijalni - relacija umjetničkog djela i autora. Umjetnik djelo stvara, u tvar utiskuje svoju ideju[1, ${ }^{[18]}$ ljubitelji ili poznavatelji umjetnosti umjetničko djelo dohvaćaju u ovisnosti o vlastitom kategorijalnom aparatu i konceptualnim odnosima. Ovo je također jedan oblik ideiranja jer se gotovom umjetničkom djelu u činu njegove prosudbe pokušava dati neko novo značenje, kao svojevrsno produženo umjetničko stvaranje. Umjetničko djelo kao istinito, dobro, lijepo i jedno omogućava da ga se prosuđuje, ali i ono samo govori o umjetnikovoj prosudbi dobroga, istinitoga, lijepoga i jednoga. Osim metafizičke dimenzije dohvaćanja ideja, umjetnik, zahvaljujući inspiracijskom procesu, može intuirati čitavu paletu ljudskih osjećaja, on nadilazi sebe zahvaljujući konaturalnoj spoznaji. Kupareo napominje da se „'compassio' ili 'connaturalitas' ne smije shvatiti u smislu neke 'sentimentalne projekcije, endopatije" (Kupareo, Um i umjetnost 86). Drugim riječima, u umjetnosti, budući da je moguć govor o umjetnosti ili konceptualno zahvaćanje umjetničkog procesa, konaturalnost nije nespoznatljivost, nego neizrecivost uobičajenim gramatičko-logičkim kategorijama. Tome je tako zato što je govor umjetnosti ujedno i govor slobode umjetnika, umjetnik vlastitu slobodu smješta u materiju, konkretnu tvar. Kao što se neizrecivo smješta kao ono neizgovoreno u govoru, a, makar po Wittgensteinu, svaki govor sadrži izgovoreno, baš kao što omeđuje i ono neizgovoreno, tako se i u umjetničkom djelu, u naravi materije nalazi i konaturalnost, kao spoznajna razina razumijevanja umjetničkog procesa i umjetničkog djela. Od konaturalne spoznaje, putem ideiranja ili zahvaćanja ideje i intuiranja ili zahvaćanja osjećaja, dolazi do rekonfiguracije tvari, ona postaje nešto drugo, uzvišeno, drugačije, višeznačno. Umjetničko djelo pripada umjetniku u konaturalnom smislu, kao i čitavom čovječanstvu, u općeljudskom smislu. Umjetnost je dakle povlašteni uvid susreta umjetnika s idejom, ideje s tvari, utvarene ideje sa svijetom i, konačno, umjetnika s univerzalnom 
ljudskošću. Umjetnost nije djelovanje koje je lišeno spoznajnog, samoodređujućeg i djelatnog smisla. Ona je, iako neminovno slijedi određenu, svakom umjetničkom izričaju vlastitu tehniku, prvorazredni čin slobodnog izbora, a ne nužnosti i mehaničkog djelovanja (Kupareo, Um i umjetnost 101).

Umjetnost nije samo carstvo lijepoga, nego može postati i područje ružnoga. Ljepota nastaje kada umjetničkom procesu, osim ideiranja, odgovara i transcendiranje. Kupareo će istaknuti kako je istinski umjetnik asketa, po tom asketizmu u svijet ulazi ljepota ili se u svijetu oslobađa ljepota, sve ostalo je skrb oko ružnoga: „Ružno u umjetnosti ne ovisi samo o slaboći, nespremnosti ili nedoraslosti gledatelja nego i slaboći umjetnika, koji ili nije ispravno intuirao neku ljudsku „ideju“ ili svoj doživljeni osjećaj nije uzdigao na sveobuhvatnost „ideje“ (Kupareo, Čovjek i umjetnost 55). Asketizam lijepoga se izravno dotiče ontologijske stvarnosti: biće jest ne-biće nije. Umjetnost je zalaganje oko bića, i to lijepog bića. No, ako tom zalaganju ne korespondira umjetnikov asketizam, tada umjesto umjetnosti imamo zanatliju koji proizvodi, ali ne stvara - trajno se udaljava od intuiranja i ideiranja. Umjetnik-asketa je sav posvećen misiji ljepote, a ako se ona ne ostvari, neizostavno slijedi proces uništavanja tog djela jer nije lijepo, jedno, istinito i dobro[19] Prosudbu umjetničkog asketizma Kupareo sažima u sljedećem postulatu: „Umjetnik je spreman uništiti svoje djelo ako u cijelosti ne odgovara njegovoj zamisli“ (Kupareo, Čovjek i umjetnost 55). Anihilacija takvog djela nije čin protiv umjetnosti, nego upravo suprotno, to je istinski čin u ime obrane umjetnosti i čovjeka.

Umjetnost, naime, nije samo u funkciji, kako je to smatrao Schopnehauer, oslobađanja čovjeka od tenzija koje život nosi i koje manifestiraju sâm život. Ona nije zastoj nečega negativnoga, pesimističnoga, nego je realitet koji, ako ga čovjek ispravno shvaća, dovodi do toga da čovjek očovječuje vlastito čovještvo, da postaje više i istinskije čovjek. Promatrač umjetničkog djela raste u ljudskosti, a ne samo u znanju o umjetničkom djelu. To se znanje posreduje posebnim vidom odgoja koje se naziva umjetničkim odgojem, a on počiva na spoznaji da se tu radi o nečemu vrijednom; odgoj počiva na ushitu²0] zbog mogućnosti uživanja u vrijednosti djela te, konačno, na nepomućenom duhovnom miru promatrača. Ovaj mir je iznimno važan jer, na primjeru filmske umjetnosti, kad promatrač u filmskom sadržaju „prepoznaje sebe (svoje ljubavi, razočaranja, mržnje itd.), lako može izgubiti 'estetsku distancu' koja je potrebna za smireno promatranje 
umjetničkog djela“ (Kupareo, Um i umjetnost 227). Razlog za potrebu nepomućenoga duhovnog mira proizlazi iz Kupareova uvjerenja da umjetničko djelo nastaje upravo u smirenosti duha umjetnika koji je suočen s idejom, a ne događajem iz vlastitog života koji ga uznemiruje, ushićuje, emocionalno zarobljava i otuđuje od zakonitosti ideiranja i intuiranja. Stanje mira koje je potrebno umjetniku da komunicira s idejom i njezinim adekvatnim „nastanjivanjem“ u neku materiju ili tvar, također je potrebno i promatraču koji ne smije sebe unositi u umjetničko djelo, nego uočavati vrijednost djela i omogućiti da se ta vrijednost „nastani“ u rastu njegove ljudskosti. Prepoznavati sebe u djelu, ne moći se distancirati od promatranoga, izvršiti svojevrsnu emocionalno-egoističnu kolonizaciju estetske forme, može samo čovjek koji nije shvatio bît umjetnosti jer nije u stanju interiorizirati kriterij i habitualnost prosude umjetničkog djela.

Umjetnik koji sebe unosi u materiju, a ne ideju, uništava djelo jer ono nije umjetničko djelo, nego trag nemoći umjetnika da prodre do ideje, da je sagleda u njezinoj jasnoći i komunicira je materiji sposobnoj primiti sadržaj i vrijednost ideje. Promatrač, pak, koji nije osnažen umjetničkim odgojem, uništava postojeće umjetničko djelo, ali, samim time, budući da je umjetnost, kao i ljepota, u svojoj osnovi jedna, a različita u mnogim izražajnim formama, uništavanjem postojećega umjetničkog djela, uništava se bît umjetnosti i ljepote jer neprepoznavanjem nestaje ideja ostvarena u konkretnoj simboličkoj formi i konkretnoj materiji. Prirodna ljepota je dostupna svim ljudima, makar u segmentiranoj prirodnosti: netko primjećuje ljepotu segmenta prirode u biljnim vrstama, netko drugi u životinjskim vrstama itd., ali uvijek se radi o dostupnosti ljepote prirode u konkretnoj prirodnosti. Kada je riječ o umjetničkom djelu i umjetničkoj ljepoti, ona je dostupna samo onima koji imaju sposobnost prepoznavanja intuiranoga i ideiranoga u konkretnom umjetničkom djelu (Kupareo, Govor umjetnosti 143-152). Umjetničko je djelo stoga prvorazredni antropološki događaj jer se njime očituje vrijednost čovjeka kao stvaratelja vrijednosti, prenositelja i usvojitelja vrijednosti.

\section{Zaključak}

Umjetnost je stvaralački proces utvarivanja ideje kojim se rekonfigurira postojeća realnost i afirmira novouspostavljena realnost umjetničkog djela. Umjetničko djelo nije destrukcija stvarnosti ni njezina negacija, ono je djelo koje ima aksiološku, etičku, antropološku i ontološku dimenziju, a ne 
samo estetsku. Estetizacija može biti, a počesto i jest, odvojena od ideiranja i intuiranja, no umjetnost i umjetničko stvaralaštvo ne može opstati bez intuiranja istine i zahvaćanja ideje ili ideiranja. Intuicijom i ideiranjem se humanizira prostorna i vremenska kategorija u koju, zahvaljujući umjetniku, ulazi novost estetizirane humane teleologije stvarajući prostor i vrijeme istinske ljudske slobode, one slobode koja nastaje intuiranjem i ideiranjem.

Odnos antropologije i umjetnosti, prema Rajmundu Kupareu, otvara čovjeka, štiti ga od spoznajne uskoće i osjećaja nepripadanja svijetu koji može opstajati i bez čovjeka. Kultura, umjetnost i historija, shvaćena kao diskurs moći o prošlosti, nastaju specifično ljudskim djelovanjem te bez čovjeka ne mogu nastati i gubljenjem odnosa s ljudskim, gubi se i njihov smisao. Antropologija otvara prostor umjetnosti, a umjetnost omogućava čovjeku da se vremeni, da djeluje u vremenu i da ostavlja trag svoga vremenjenja svim ljudskim bićima čija je mjera ljudskosti određena humanom teleologijom. Zašavši u zakonitost humane teleologije, umjetničko djelo postaje samostalna datost, realnost u sebi, i premda nikada ne gubi odnos s autorom-umjetnikom koji je ideiranjem i intuicijom omogućio susret ideje i tvari na način nastanka nečega novoga, umjetničko djelo biva predano ljudskom svijetu sposobnom stupiti u odnos s vrijednošću toga djela. Humana teleologija omogućava da se odnos antropologije i umjetnosti poima kao odnos slobode umjetnika koji je vlastitu slobodu utisnuo u tvar te tako omogućio da umjetničko djelo bude slobodno, otvoreno za mnoge odnose s ljudima osjetljivima na slobodu, istinu, ideju i ljudsko. Humana teleologija omogućuje umjetničkom djelu da imitira vremenjenje umjetnika, samo što se ono vremeni u kulturi i povijesti te se tako otvara svim ljudskim bićima koja shvaćaju vrijednost kulture i povijesti, a napose vrijednost umjetničkog djela koje nastaje procesom ideiranja i intuicije te opstaje kao antropološki događaj, odnosno kao događaj odnosa čovjeka i utvarene vrijednosti.

\section{Bibliografija}

Fabro, Cornelio. Libro dell'esistenza e della libertà vagabonda. Edizioni Piemme, 2000.

Fabro, Cornelio. Tra Kierkegaard e Marx. Edizioni Logos, 1978.

Gadamer, Hans-Georg. Nasljeđe Europe. Preveo Kiril Miladinov, priredio Damir Barbarić, Matica hrvatska, 1997. 
Gehlen, Arnold. Čovjek: Njegova narav i njegov položaj u svijetu. Preveo Kiril Miladinov, Breza, 2005.

Kupareo, Rajmund. Balada iz Magallanesa. Dominikanska naklada Istina, 1978.

Kupareo, Rajmund. Čovjek i umjetnost. Kršćanska sadašnjost, 1993.

Kupareo, Rajmund. Govor umjetnosti. Kršćanska sadašnjost, 1987.

Kupareo, Rajmund. Nad kolievkom srdca. Kralj, 1945.

Kupareo, Rajmund. Pjesme. Kršćanska sadašnjost, 1980.

Kupareo, Rajmund. Prebivao je među nama. Sveučilišna naklada Liber, 1985.

Kupareo, Rajmund. Svjetloznak. Golden Time, 1994.

Kupareo, Rajmund. Um i umjetnost. Glas Koncila, 2007.

Kupareo, Rajmund. Umjetnik i zagonetka života. Kršćanska sadašnjost, 1982.

Kupareo, Rajmund. „Osnovne crte Tomine umjetnosti“, Crkva u svijetu, no. 4, 1988, pp. 186-91.

Kupczak, Jarosłav. Destined for Liberty. The Catholic University of America Press, 2000.

Labus, Mladen. Filozofija moderne umjetnosti. Znanost i društvo, 2006.

Plessner, Helmuth. Conditio humana. Filozofijske rasprave o antropologiji. Preveo Branko Despot, Nakladni zavod Globus, 1994.

Vattimo, Gianni. Kraj moderne. Preveo Mario Kopić, Matica hrvatska, 2000.

Woznicki, Andrew Nicholas. The Dignity of Man as a Person. Society of Christ, 1987. 
[1] Ideal čovječnosti se ostvaruje u napuštanju animalnosti, čovjek je čovjek ne po onome što je u prirodi rođenjem zatekao, nego prvenstveno po mogućnosti inkulturiranja vlastite osobe u ljudsku povijest, kao i po mogućnosti da stvara tu povijest. Tada za čovjeka možemo reći da je ,jedna životinja koja iza sebe ostavlja životinjstvo“ (Plessner 105).

[2] Kupareo prihvaća skolastičko određenje intuicije. „Specifična oznaka intuitivne spoznaje jest njezin karakter neposrednosti, koja je suprotna diskurzivnoj funkciji rasuđivanja: ta se neposrednost nameće bez pomoći nekog gnoseološkog ili psihološkog sredstva. Ne isključuje se, dakako, species impressa. Druga vrsta intuicije bila bi spoznaja vlastitog „ja“ koja se poklapa sa sviješću vlastitih aktivnosti: ta je spoznaja intuitivna samo kao iskustvo, ali ne kao spoznaja nečega različitog od vlastitog „ja“; nemoguće je nešto spoznati bez pojma koji je intencionalno upravljen k objektu, neovisnom o mišljenju“ (Kupareo, Čovjek i umjetnost 80-81).

[3] C. Fabro napominje kako se ovaj problem nadilazi samo ako se ima na umu da filozofija tematizira dva bitna područja: ja i bitak (Fabro, Libro dell'esistenza 25).

[4] Apologija destruirane stvarnosti rezultira i destrukcijom filozofijske estetike koja slijedi iz smrti umjetnosti. Vattimo analizira Benjaminovu tezu „rastresene zamjedbe“ i dolazi do zaključka kako se u epohi tehničke hiperprodukcije „umjetničko iskustvo (više) ne daje, ili se (još) ne daje“ (Vattimo 59).

[5] lako se umjetničko djelo promatra u kontekstu moralne dimenzije, treba naglasiti kako umjetnik nije kreator morala, nego umjetničkog djela. On putem imaginacije izražava različite konstitutivne elemente čovjeku navlastitog postojanja (Kupareo, Um i umjetnost 116-18).

[6] M. Labus vrednovanje moderne umjetnosti utemeljuje na sljedećem polazištu: „Iz mišljenja bitka modernog čovjeka, misli se i bitak moderne umjetnosti: on nije dohvatljiv izvan bitnog mišljenja, ali i „ontološka sudbina“ umjetnosti postaje odlučujuća za bit(ak) čovjeka i njegovu sudbinu“ (Labus 15).

[7] Privativno se odnosi na nedostatak onoga što nekom biću upravo kao takvom biću pripada.

[8] Kontingentna bića ne mogu razumjeti logiku skrbi, ali su zbog toga pozvana, kada čovjeka promatramo kao kontingentno biće, postavljati pitanja. Pitanja su upravo najvlastitiji izraz 
kontingentnosti, ona traže odgovore na pitanja svih mogućih načina nečega što jest. Kupareo u trima dramama posvećenim pashalnom misteriju, u Josipovim pitanjima uprizoruje egzistencijalni značaj kontingentnosti: „Zašto je onda dopustio da ga taj Duh napusti? Zašto je umro sramotnom smrću na križu?" (Kupareo, Prebivao je 84). Odgovor na ova pitanja nalazi se izvan zatvorene krivulje kontingentnosti, ali, na simboličkoj razini, upravo zbog otvorenosti koju jamči upit, pripadaju svijetu kontingencije. Analogno ovome, umjetnost je simbolička forma ili upitnost onoga čiji se na vlastiti bitak nalazi izvan zatvorene krivulje poznatog, znanog i neupitnog svijeta.

[9] Personalistički vidik na koji se poziva Kupareo zasnovan je na tomističkoj i fenomenološkoj osnovi putem koje se čovjek, kao biće istine i slobode očituje u činu. K. Wojtyła je čovjeka zbog toga promatrao kao osobu-čin. Zanimljivu recepciju personalističkog nauka, pod vidom realizma u etici, iznosi J. Kupczak (Kupczak 86-94).

[10] Cjelovitost čovjeka konstituirana je od tri elementa: tjelesnoga, psihičkoga i duhovnoga. Iz jedinstva, a ne iz trijade, ovih ontičkih elemenata, čovjek manifestira vlastitu istinu (Woznicki 21).

[11] Cjelovito ljudsko biće nadvladava dualističke koncepcije. Apsolutizacija i ontološka separacija negiraju da čovjek bivstvuje i djeluje kao osoba (Fabro, Tra Kierkegaard e Marx 77).

[12] Umjetnička dimenzija spacio-temporalnog kontinuuma u sebi uključuje ludičnost. Kupareo u jednoj pjesmi, naslovljenoj Igra vremena, pokazuje odnos kulture, kao bitno ljudskog djela, i čovjeka koji stari u toj kulturi, pripada joj. Kultura čovjeku uprizoruje njegovu vlastitu vremenitost, poziva ga da ne pristane na proces starenja kao proces jednostavne prisutnosti, nego da stareći iščitava simboličke forme sadržane u kulturi i da stvara kulturu simboličkih formi (Kupareo, Pjesme 110).

[13] Humani subjekt, putem umjetnosti, prepoznaje zahtjev za suživotom. Analizirajući Andrićevo djelo Na Drini ćuprija, Kupareo ističe kako se suživot ostvaruje međusobnim poštivanjem, a ono se očituje u svijesti zajedničkog umiranja. Magija piščeve riječi opisuje patnju i umiranje u kontekstu zajedničkog života, koji briše sve razlike (Kupareo, Umjetnik i zagonetka života 118-20).

[14] Negacija je oblik moći, a o nju Kupareo u pjesmi „Moć“ određuje kategorijom prošloga, nestaloga:,Moćsiva avet bez krilagdje je sada njezina sila?Već ju je davno progutalaNoć“ (Kupareo, Svjetloznak 194). 
[15] Čovjek je, kao biološko biće, slab i nemoćan pred prirodom, ali je tu svoju nemoć, zahvaljujući inteligenciji i mogućnosti djelovanja, proizvođenja predmeta i novih, ljudskom snagom stvorenih zakonitosti, nadišao vlastite nedostatke. Čovjek se u prirodi kreće kao inteligentno i uspravno biće, slobodnih ruku (Gehlen 29).

[16] Estetski užitak pripada korpusu subjektivnih činjenica, baš kao što ljudski život pripada korpusu bioloških činjenica. No, da bi se od činjenica prešlo na smisao, činjeničnost treba nadići ono zašto, kao osmišljavajuću razinu neke datosti. Priču „Konac ljubavne priče“ Kupareo piše slijedeći F. D. Dostojevskoga, koji u djelu Braća Karamazovi ističe kako se tajna ljudskog života razotkriva u onome što slijedi nakon postavljenog pitanja o tome zašto se živi. Odgovori mogu biti najrazličitiji, ali svakako nadilaze ono kako se živi. Njegov lik, sadašnji taksist, a nekadašnji svećenik Miguel daje odgovor: „Propala firma, propao ja, propao brak“ (Kupareo, Balada iz Magallanesa 97). Smisao života i nije moguće drugačije izreći nego propadanjem svega što propadanju pripada.

[17] Na primjeru pjesničke riječi, moguće je shvatiti, smatra Kupareo kako ona biva „simbolom („symbóllo“ - sjedinjujem, sastavljam) skrovitog odnosa stvari i ideja (intuiranog osjećaja) zato je i pjesnička forma nerazdjeljiva od sadržaja, a njezin ritam odražava narav tog jedinstva: njegovo savršenstvo ili nesavršenstvo“ (Kupareo, Govor umjetnosti 39). Odvojena jednoća umjetničkog djela stoga uvijek sadrži konstitutivnu tajnu odnosa ideje i tvari.

[18] Umjetnikovo zahvaćanje ideje odvija se onkraj svih naučenih formi i vještina. Čovjek kojemu se objavljuje ideja, više ne čuje, ne vidi, ne razumije ono što je susretu s idejom prethodilo. Ideja je novost koja ne može biti okovana onim dosadašnjim. Kupareo tako u pjesmi „Doček“ kaže: „Zaludu je šaptat pozdrav naručeni,jer ja sam, ljudi, postao gluh“ (Kupareo, Nad kolievkom srdca 26) Gluhoća o kojoj Kupareo govori, gluhoća je na dosadašnjost i ona omogućava da se ljudskost obogati drugačijim govorom, objaviteljskim govorom vrijednosti.

[19] Djelo koje umjetnik nije uništio, a mogao ga je i trebao uništiti, gubi svoju samorazumljivost i postaje kič. Kič može služiti plemenitim i neplemenitim svrhama te ga kao takav fenomen treba i razumjeti (Gadamer 57-59). 
[20] Ushit (raptus) se razlikuje od zanosa (extasis) jer ushit ne odvaja čovjeka od uma i misaonosti, dok zanos čovjeka dovodi u situaciji da bude izvan sebe i stoga „spada u afektivno područje zbog ljubljenog predmeta ili osobe“ (Kupareo, Čovjek i umjetnost 59).

\section{(c) (i) (9)}

Creative Commons Attribution-NonCommercial-NoDerivatives 4.0 International License 